\title{
Papers
}

\section{Understanding urban attitudes towards country towns: considering their potential as visitor attractions}

Received (in revised form): 28 July 2006

\section{Neil A. Powe}

is a lecturer teaching in planning and is based in the School of Architecture, Planning and Landscape at Newcastle University. He has two key research interests: non-market valuation and rural planning. Within his rural planning research, recent efforts have focused on finding a future for county/market towns, with this paper considering the role that urban visitors can play in finding a successful strategy for their town centres.

\begin{abstract}
Country towns can often provide attractive and distinctive visitor locations for urban residents. Attracting urban visitors can help alleviate problems of maintaining trade for their town centres. Despite this potential, little is known about how urban residents view country towns and what they find attractive. Through the use of focus groups and questionnaire surveys, the research demonstrates the key attraction of country towns to be that of providing something 'different from the city' in terms of history, tradition and shopping. An important element of this attraction is the socially constructed meaning of the term 'market town', which reflects the size, history and tradition of these towns as well as their rural hinterland linkages. Indeed, visitor rates were highest for the most 'typical' market towns. This is particularly reflected in shopping patterns, where there are expectations in terms of local food and crafts. Owing to the need for most towns to maintain their 'core' local trade, the paper has also considered the consistency of efforts to encourage both urban visitors with resident populations. Although there are some parallels, particularly where people have moved to country towns in order to experience their 'different from the city' character, care must be taken to balance the potential of attracting urban residents and that of maintaining the rural service centre functional role.
\end{abstract}

Neil A. Powe

Centre for Research in Environmental Appraisal and Management (CREAM) School of Architecture Planning and Landscape

University of Newcastle upon Tyne Newcastle upon Tyne

NE1 7RU, UK

Tel: +44 (o) 1912227570

Fax: +44 (o) 1912228811

E-mail: n.a.powe@ncl.ac.uk

\section{Keywords:}

market towns, rural recreation, local foods and crafts, town centres

Journal of Retail and Leisure Property (2006) 5, 255-269.

doi:10.1057/palgrave.rlp.5100031 


\section{INTRODUCTION}

Country towns have an important role to play as rural service centres, with those living in the towns themselves and rural hinterlands often making up the majority of the visitors to their town centres. ${ }^{1-3}$ These small town centres are, however, facing serious challenges as residents are being diverted elsewhere for shopping and employment. ${ }^{3-7}$ With high levels of car ownership, and motoring costs falling as a proportion of disposable income, ${ }^{8}$ this has enabled rural residents to travel further a field in order to gain higher quality services and better employment prospects. ${ }^{9}$ These trends have been reflected in terms of increased concentration of retail activity into larger centres, where, for example, in England, 75 per cent of non-food sales (such as fashion and gifts) are now in the top 200 retail centres compared to 50 per cent in the early 1980 s (English Market Towns Advisory Forum, 2002). As such, country towns are losing out particularly in terms of comparison shopping. ${ }^{1,3}$ As country towns can often provide attractive and distinctive visitor locations, the increase in mobility encourages urban residents to visit in increasing numbers for recreation and leisure shopping. Through recognising this potential, extra trade can be generated by marketing country towns in terms of the 'something different' that they provide. Linking such efforts to improving recreational facilities within towns may be crucial for their regeneration.

Country towns differ widely in size, location and other characteristics, but often share a common capacity to act as focal points for trade and services for their rural hinterlands. Indeed, towns playing this role have been labelled as 'market towns' ${ }^{10}$ within British Government Policy, and their rural centre functional used as a justification for government support. ${ }^{11}$ This paper considers an alternative definition of 'market towns', which is socially constructed and is a key motivation for people from urban areas to visit country towns. In contrast to the dictionary definition, it was hypothesised that the term 'market towns' has a deeper historical and cultural meaning than 'a town where a market is held' ${ }^{12}$ It is this wider cultural and historical meaning of the term which is being used within publicity material for British towns.

Despite the use of the term 'market town' within marketing efforts to encourage urban visitors, little is known about how urban residents view country towns and the extent to which their market town nature is attracting visitors. For example, urban visitors may expect a marketplace to provide the centre of the town. Other typical features may also include castles, guildhalls and churches. Country towns have also often provided a traditional meeting place and urban residents may have the expectation that fairs and festivals will be held in the towns. Furthermore, as the origin of many of our country towns is to be found in their agrarian past, urban residents may look to purchase local quality food. As little is known about urban attitudes and expectations when visiting country towns, these ideas represent only speculation. To increase knowledge of urban attitudes and expectations, this paper investigates:

- the extent to which a socially constructed definition of 'market towns' exists and its meaning 
— urban resident activities and preferences towards visiting country towns

- the consistency of such findings with the preferences and activities of resident populations.

Through the use of focus groups and questionnaire surveys, this research helps assess the potential for country towns to enhance their role as visitor attractions without compromising the important role they play as service centres for town and hinterland populations.

\section{UNDERSTANDING THE IMPORTANCE OF THE VISITOR ATTRACTION ROLE}

There is little evidence available in terms of the current importance of urban visitors to country towns, with perhaps the only study available suggesting urban visitors make up between 1 and 16 per cent of those interviewed on a next to pass basis within town centres. ${ }^{1}$ For some towns the dependence on tourism is greater, which indeed was demonstrated during the foot and mouth crisis ${ }^{13}$ for the town of Keswick, in Cumbria North England. ${ }^{14}$ This crisis illustrated the importance of country town location near rural visitor attractions, where sizeable loses were reported in trade despite there being no restrictions due to the foot and mouth disease on visiting the towns themselves. As such, the visitor attraction role should not be considered in isolation from the character of its surrounding rural hinterland.

Powe et al. ${ }^{15}$ provide a wider study of over 200 English country towns in which they explore the extent to which they provide visitor attractions. Using cluster analysis, three types of visitor attraction towns were identified all of which are of relevance to urban day-trippers: top visitor attractions ( 3 per cent of towns); key visitor attractions (10 per cent of towns) and day-tripper locations (29 per cent of towns). The first two visitor attraction groups are similar, but differ mainly in terms of the extent to which they are visitor attractions. These two types of visitor attraction tend to be remote from other urban areas and are often located near the coast or national parks. The third visitor attraction group of towns is often without campsites or a high proportion of employment in hotels and catering, but consistently have a higher than average number of visitor attractions. For such towns, day-trippers are likely to be important to retailing in the towns. Although the majority of towns (59 per cent) were not identifiable as visitor attractions, spatial clustering was such that visitor attraction towns were typical in the English counties of East Sussex, Worcester, Northumberland, Cumbria, County Durham, Herfordshire and Devon. As such providing visitor attractions would appear to be important for the rural economy in these counties, two of which are within the North East of England case study area. Further analysis using regression found similar results but also a link between the percentage of employment in hotels and catering and the number of comparison shops in the towns. This suggests the importance of visitors to the support of comparison-shopping. 


\section{ATTRACTING VISITORS TO COUNTRY TOWNS}

Having gained an understanding of the importance of the visitor attraction role, it is also necessary to consider what it is that attracts visitors to country towns. The New Economics Foundation (NEF) ${ }^{16}$ provides an insight by considering the extent of 'clone towns' in Britain. Clone towns occur where 'the individuality of high street shops has been replaced by a monochrome strip of global and national chains' (p. 10). The opposite is defined as a 'home town', which is 'a place that retains its individual character and is individually recognisable and distinctive to people who live there, as well as who visit' (p. 15). $\mathrm{NEF}^{16}$ developed a methodology whereby the extent to which a settlement is labelled a 'clone town' depends upon the existence of independent shops. From 103 towns investigated in Britain with between 5,000 and 150,000 population, 42 per cent were identified as clone towns, 34 per cent as home towns and 27 per cent are a mixture between the two. Of particular relevance to this paper is the finding that places with higher population are more likely to be classed as clone towns, and, smaller towns, such as country towns, were more likely to be classed as home towns. This evidence suggests that country towns are likely to provide a different type of shopping to most large urban areas. Indeed, there is great diversity between country towns that may also add to their attraction. ${ }^{17}$

Despite the importance of their research, $\mathrm{NEF}^{16}$ did not consider to what extent clone or home towns are preferred by shoppers. This is crucial because, if urban and town residents desire well known high street names when shopping, the different nature of shopping provided within country towns is unlikely to attract much in the way of trade.

Interestingly, in their comparison of new and older housing in Penrith in Northern England, Richardson and Powe ${ }^{18}$ found in-migrants to the town were less likely to prefer shopping in chain stores ( 45 per cent inmigrants and 64 per cent other residents) and generally demonstrated more favourable attitudes towards shopping in Penrith than longer-term residents. As a large number of in-migrants were from larger urban areas, this perhaps reflects their choice to move to the town.

Further to the high proportion of chain stores, another characteristic of urban shopping is the opening hours, often open Sundays and late during the week. Country towns tend not to be open on Sundays, are rarely open late and usually have half day closing on one day during the week. Urban residents used to a better service may struggle with the lower level provided in county towns.

Cheshire and Stabler ${ }^{19}$ suggest that visitors differ in terms of the purpose of their day out. In their study of visitors to a beauty spot in Berkshire in South England, they found that 45 per cent of their sample could be labelled as 'pure' visitors whose sole purpose was to visit the site, 38 per cent whose were having a multi-purpose outings and 17 per cent 'meanderers' who were just out for a drive. These results are important as 'pure' visitors are most likely to engage with the towns and provide more trade. This demonstrates the importance of having sufficient visitor attractions in a town to attract 'pure' visitors for the whole day.

Even if towns provide the appropriate visitor attractions, they still need to be publicised. Traditional publicity for country recreation has been 
expensive as it involves promotional literature such as brochures and leaflets. According to Cooper et al. ${ }^{20}$ the production of such promotional literature accounts for the largest proportion of most marketing budgets within the tourism sector. With the increased popularity of the internet, there are prospects of reducing such publicity costs. Indeed, Faulkner et al. ${ }^{21}$ suggests consumers are relying more on electronic media to obtain destination material, which is much cheaper to provide.

\section{CASE STUDY OF THE NORTH EAST}

Newcastle and North Tyneside is a large urban area, with the Population Census 2001 showing there to be approximately 451,995 people living within the conurbation north of the river Tyne. The North Tyne conurbation is located near to the rural county of Northumberland and the lesser rural county of Durham. Directly South are the urban areas of Gateshead and Sunderland. There are 14 country towns in the North-East of England, which are potential visitor destinations for urban residents from the North Tyne conurbation: Alnwick, Amble, Barnard Castle, Berwick-upon-Tweed, Bishop Auckland, Corbridge, Crook, Haltwhistle, Hexham, Morpeth, Prudhoe, Rothbury, Stanhope and Wooler. Powe et al. (forthcoming) categorised Barnard Castle, Stanhope, Alnwick, Amble, Berwick upon Tweed, Rothbury and Wooler as remote from both larger urban areas and other towns. Morpeth and Corbridge are the nearest of the towns to the North Tyne area. Only Haltwhistle, Crook, Corbridge and Bishop Auckland were categorised as not visitor attractions, with Berwick upon Tweed, Hexham and Wooler in the key visitor attraction category (largely based on their dependence of employment from hotel and catering). The remaining towns all are visitor attractions, but can be regarded more as day tripper locations. Generally the affluence of northeast towns is below that of the English average for country towns.

\section{METHODOLOGY}

\section{Urban survey}

Given the lack of previous research, it is essential to first gain an understanding of the range of behaviour and opinions regarding leisure trips to country towns. This can be achieved using focus groups, which are small group meetings directed by a moderator that provide a permissive, non-threatening environment that enables discussion. ${ }^{22}$ Although given the numbers involved it is unlikely that the findings will be statistically representative, focus groups are particularly useful for understanding the range of issues and provide depth of understanding that cannot easily be achieved within a questionnaire survey.

Two focus groups were held in Gosforth, a suburb not far from the centre of Newcastle upon Tyne. A location for the meetings was chosen around which there were a variety of housing (reflecting different socioeconomic groups) and participants recruited door to door with a 220 incentive to encourage people with a range of experience to attend. The pilot questionnaire provided the main focus for the discussion, with the structure for the discussion predetermined to reflect issues of interest and 
concerns regarding the questionnaire. These were sequenced within a protocol, which consists of dialogue and a series of open-ended questions. The meetings lasted approximately $1.5 \mathrm{~h}$ and were led by an experienced facilitator. As well as an excellent means of piloting the questionnaire, analysis of the meetings provided a wealth of information that helped understand the results within the questionnaire survey. A total of 16 participants were involved in the meetings (10 participants in group 1 and 6 in group 2). Everyone attending had previously visited country towns, with most of the participants having recently visited at least one town.

The main survey followed the focus groups. The questionnaire consisted of three sections: days out; visits to country towns; and questions about the respondent. The first section was a gentle introduction eliciting information regarding 'days out' in general. The second section started by asking respondents to rank from a list of country towns in the North-East of England the three towns that they feel are most like market towns. This was followed by an open-ended question that asked them to explain what the term 'market towns' means to them. The respondents were then asked questions about the country towns in the northeast they had visited and which activities they have undertaken. This was followed by a series of open-ended questions regarding attitudes and preferences towards these towns. The last section contained a series of questions about the respondent, including if they have friends or relatives living in country towns, membership of relevant groups, employment status, housing-type and age.

The North Tyne survey was undertaken within November 2005, with the questionnaire being delivered house-to-house, with a stamped addressed envelope enclosed for completion. A total of 750 questionnaires were delivered, with 148 questionnaires being returned (20 per cent response rate), with the response rate varying considerably between area (Gosforth, 33 per cent; Heaton, 15 per cent, Jesmond, 18 per cent, Wallsend, 9 per cent, Whitley Bay, 23 per cent). A further four questionnaires were returned from disabled respondents who explained they were no longer able to visit country towns. Despite efforts within the questionnaire and covering letter to encourage response from all participants, the response rates suggest a self-selection bias by those interested in visiting country towns, with the highest response rates being linked to the affluence of the areas considered.

\section{Morpeth surveys}

The Morpeth surveys were undertaken in 2005 as part of consultancy work for the Castle Morpeth Borough Council and Morpeth \& District Chamber of Trade. As such, only the parts of the study are relevant to this paper will be discussed. This research involved a survey of retailers in the town (112 questionnaires with a 66 per cent response rate), a survey of town centre visitors (415 questionnaires with one in five people stopping to be interviewed) and a survey of residents within the town and nearby large village of Pegsworth (325 questionnaires completed with a 50 per cent response rate). As further details of surveys are available elsewhere, ${ }^{23}$ only the essential details are provided within this paper. ${ }^{24}$ 


\section{ANALYSIS \\ Focus group results}

Respondents were asked within the focus groups what the term 'market town' means to them. For some people this was easy, but for others they found it easier to tell you which settlements were and were not market towns. In the case of the latter, meaning was elicited through probing. Part of this meaning was derived from the 'traditional' linkages with the rural hinterland, particularly agriculture and the livestock market. Generally, market towns were perceived not to be large but of a reasonable size to support their hinterlands and prosperous/middle class/attractive/safe places to bring up children and retire. An important general principle and something that attracts urban residents is the idea that market towns are 'different from the city'. Prosperity and safety is part of this, but also their character in terms of history, pace of life and tranquillity. A key aspect of market towns particularly singled out was the shopping experience, where shops were seen to have character, individuality, be more local and specialist in nature and provide a quainter environment for shopping. As way of an illustration one participant said: 'I can go to Leeds, I can go to Manchester and it is the same shops. So why should I go there. I would rather go to these smaller places and stop and look at individual shops'. Towns that were not considered to be market towns were seen not to have the sufficient history or that their history was indicative of a different role such as seaside (Amble) and/or border town (Berwick upon Tweed) or based more on industry and coal mining (Bishop Auckland). Location was also found to be important, where one town was considered to be an urban suburb (Prudhoe) and another too small (Wooler) to be classified as a market town.

As with the findings of Cheshire and Stabler, ${ }^{19}$ the purpose of visits to country towns seemed to be split between those who see them as a place to visit as part of a day out in the country and those for which visiting a country town is the main purpose of their outing and will tend to spend the whole day at the town. In the case of the former, visits to country towns will be dependent on the location of such towns near the Northumberland National Park or the Northumberland Heritage Coast for example. Indeed, one participant stated: 'I might visit the town for a walk, so I wouldn't go there to shop particularly but whilst we are there we might do a bit of shopping'. 'I really like market towns but I find them a bit boring if I stay too long'. In the case of participants visiting a country town for a whole day one participant stated: 'quite a few of them [country towns] are nicely preserved and have nice parks'. I've got grand children so we go somewhere like Morpeth and we can go to the park and things like that can be a multiattraction. You can go off and do some shopping and have something for the kids'. These findings suggest the need to have a range of attractions, which are likely to include historic buildings, garden centres and specialty shops.

The reasons for visiting these settlements related to the definition of market towns previously described, where a key reason was the experience 'not being like the city', where this difference related to more than size. This difference was particularly noted for shopping, where 
Table I: Choice of most typical and popular market towns

\begin{tabular}{lcccl}
\hline & I st choice (\%) & $\begin{array}{l}\text { Chosen in top } \\
\text { three (\%) }\end{array}$ & Visiting (\%) & $\begin{array}{l}\text { Av. no. visits (last } \\
\text { I2 months) }\end{array}$ \\
\hline Hexham & 39 & 71 & 69 & 3.6 \\
Alnwick & 20 & 67 & 72 & 3.2 \\
Morpeth & 11 & 43 & 66 & 3.3 \\
Corbridge & 8 & 26 & 56 & 2.9 \\
Berwick upon Tweed & 7 & 18 & 31 & 2.4 \\
Rothbury & 6 & 26 & 40 & 2.3 \\
Barnard Castle & 3 & 12 & 30 & 1.6 \\
Amble & 2 & 6 & 38 & 2.8 \\
Bishop Auckland & 1 & 2 & 10 & 1.8 \\
Wooler & 1 & 9 & 22 & 1.1 \\
Haltwhistle & 1 & 4 & 18 & 1.3 \\
Prudhoe & 0 & 0 & 14 & 1.2 \\
Stanhope & 0 & 0 & 11 & 1.6 \\
Crook & 0 & 0 & 6 & - \\
Sample & 148 & 148 & 148 & \\
\hline
\end{tabular}

participants suggested that they would buy the 'things that you just can't get in the city' or at least 'not the general run of the mill shopping'. It was perceived that country towns are likely to be more expensive, so the shopping is not for bargains but instead for 'originality', 'authenticity' and 'quality'. An exception perhaps is the many charity shops located in country towns, where opinion was mixed as to whether this was a good thing. Based on the traditional agricultural linkages, local food produce was popular for both shops and restaurants.

\section{Questionnaire results}

Analysing the 148 responses to the questionnaire survey, the average age was a little higher than that of the wards from which the survey was undertaken. Considering the age distribution, this was largely due an over representation from the 55 to 75 age group. Membership of environmental/heritage organisations was high with, for example, 30 per cent of respondents were members of the National Trust compared to the 14 per cent average for British households. ${ }^{25}$ These results suggest an element of self-selection bias, where those most interested in country towns were more likely to answer. Despite this, the results are still very useful and corroborate the focus group analysis.

Following the initial questions about trips out, the questionnaire then explored the meaning of the term 'market towns'. Due to task simplicity, respondents were initially asked to choose from the list of country towns in the North-East of England their top three in terms what they consider to be most typical market towns. Table 1 presents the results in order of popularity. From this list, clearly Hexham, Alnwick and Morpeth are the top three, with Corbridge, Bewick upon Tweed and Rothbury also being popular. These are all small rural towns, with historical rural hinterland linkages. Table 2 provides a brief description of the top three towns.

Having chosen the 'typical' market towns, respondents were then asked to describe the meaning of the term. Only 11 respondents failed to give a meaning and a further six did not add to the dictionary definition. From the remaining respondents some informative definitions were stated. The 
Table 2: Description of the most typical 'market towns'

\begin{tabular}{|c|c|}
\hline Alnwick & $\begin{array}{l}\text { Alnwick, with a population of approximately } 8,000 \text {, serves a dominantly rural hinterland and holds } \\
\text { sway in a sub-region between the other market towns of Morpeth and Berwick upon Tweed. Its } \\
\text { origins owe much to its strategic position close to the Scottish border, defending the lands of the } \\
\text { Dukes of Northumberland. Tourism is important with the town centre castle being a key visitor } \\
\text { magnet (now of Harry Potter fame) and water gardens providing a more recent attraction }\end{array}$ \\
\hline Hexham & $\begin{array}{l}\text { Hexham, population of approximately II,000, is situated in the Tyne Valley. It is a gateway to the } \\
\text { Northumberland National Park. It lies in the Newcastle to Carlisle corridor (two cities in the } \\
\text { North of England) carrying both road and a passenger/freight railway. Tourism plays a central role in } \\
\text { the life of the town, capitalising on the area's Roman heritage and abbey which dates back to } \\
647 \text { AD }\end{array}$ \\
\hline Morpeth & $\begin{array}{l}\text { Morpeth, with a population of approximately } 13,500 \text {, is situated in the Wansbeck valley } 15 \text { miles } \\
\text { to the north of Newcastle Upon Tyne. Morpeth is the centre for administration in the county and } \\
\text { has a railway station on the North East main line. Tourism is important to the town with the 13th } \\
\text { century Chantry that houses a Bagpipe Museum being a key attraction }\end{array}$ \\
\hline
\end{tabular}

most common responses related to the history/old/traditional aspects of the towns ( 32 per cent), their size ( 31 per cent) and their country/rural/ remote location ( 29 per cent). Market towns were also seen by a number of participants ( 20 per cent) to provide a focus for their rural area, and other respondents noted their linkages with agriculture ( 7 per cent) and availability of local produce ( 9 per cent). The 'different from the city' nature of the shops was also noted by a number of the respondents (15 per cent), suggesting the shops to tend not to belong to a chain and be specialist. These results are very similar to those stated within the focus groups. Further confirmation of these findings was provided when analysing responses to an open-ended question asking what urban residents like about country towns. The most frequently stated issue was the difference from city life ( 37 per cent), with specialist shops ( 31 per cent) being the most commonly stated aspect of this. Other issues stated by respondents that can also distinguish country towns from city life are the buildings (18 per cent), history (18 per cent), size (11 per cent), peacefulness (11 per cent), rurality ( 7 per cent) and friendliness ( 7 per cent). Dislikes about market towns related to parking problems (mostly difficulties finding a space) (37 per cent), congestion in the towns (27 per cent) and problems with shops and cafes (19 per cent) (recent increase in chain stores, charity shops and limited opening hours).

Table 1 also shows the popularity of the country towns in terms of the percentage visiting in the last 12 months and the average number of visits made within that period. It is interesting to note that the top three typical 'market towns' are also the top three in terms of popularity. Corbridge is also notable for the majority (56 per cent) of respondents having visited in the last 12 months. Within the focus groups it was identified that visitors to country towns either seemed to see them as a place to visit as part of a day out in the country or as the main purpose of their outing, spending the whole day at the town. Clearly, the latter group could be considered to be more important in terms of their effects on the economy of the towns. When asked this within the questionnaire survey, the results were very similar to that of Cheshire and Stabler, ${ }^{19}$ with 45 per cent of respondents saw visiting country towns as the main purpose of their day 
Table 3: Facilities visited in country towns

\begin{tabular}{|c|c|c|}
\hline & $\begin{array}{l}\% \text { visiting in a } \\
\text { country town }\end{array}$ & Which towns? (\% of those using the facility) \\
\hline Teashop or café & 70 & Alnwick (35\%), Hexham (35\%), Corbridge (33\%) \\
\hline Public house & 68 & Corbridge (36\%), Hexham (3I\%), Morpeth (26\%) \\
\hline Garden or park & 66 & Alnwick (69\%), Morpeth (24\%), Hexham (14\%) \\
\hline A meal in a restaurant & 63 & Hexham (29\%), Alnwick (27\%), Corbridge (27\%) \\
\hline Castle or other historic building & 60 & Alnwick (65\%), Hexham (17\%), Barnard Castle (15\%) \\
\hline Craft/art shops & 51 & Corbridge (36\%), Alnwick (29\%), Hexham (28\%) \\
\hline Specialist food shop & 50 & Corbridge (43\%), Morpeth (26\%), Hexham (21\%) \\
\hline Book shop & 44 & Alnwick (65\%), Hexham (32\%), Morpeth (25\%) \\
\hline Clothes shops & 41 & Hexham (44\%),Alnwick (30\%), Morpeth (30\%) \\
\hline Spent the evening & 40 & Corbridge (25\%), Alnwick (24\%), Hexham (22\%) \\
\hline Regular market & 37 & Hexham (39\%),Alnwick (24\%), Morpeth (19\%) \\
\hline Farmers market & 30 & Hexham (45\%),Alnwick (I8\%), Morpeth (I4\%) \\
\hline Antique shops & 29 & Hexham (40\%), Corbridge(20\%), Rothbury (20\%) \\
\hline Museum & 28 & Barnard Castle(48\%),Alnwick(I4\%), Hexham(I2\%) \\
\hline Festival or fair & 25 & Alnwick (49\%), Hexham (22\%) \\
\hline Garden centre & 25 & Morpeth (45\%), Hexham (19\%), Alnwick (16\%) \\
\hline
\end{tabular}

out and 26 per cent not. The remaining 26 per cent explained this varied too much to say. This suggests country towns are self-contained visitor attractions in their own right and need to have sufficient activities to maintain the interest of visitors for the whole day. Towns failing to do this are unlikely to provide the visitor experience that nearly half of the respondents require.

In order of popularity, Table 3 reports the activities undertaken by respondents in the country towns, with the second column providing the percentage having visited (ever) and the third column the top three towns that have been visited for that activity. The evidence suggests that the most common activity by urban residents in country towns is to purchase snacks/refreshments/meals and visiting gardens or historic buildings. The majority of the respondents had all performed these activities. Perhaps secondary to this, but still performed by the majority of respondents, was shopping in craft/art shops and specialist food shops. Other shops were also popular, for example, book, clothes and antique shops. Garden centres were the least popular of the shopping activities. A sizeable minority of respondents had previously visited regular and farmers markets in the country towns.

Focusing on shopping in more detail, respondents outlined what they have usually bought in country town shops. Although a small number of the respondents may have confused shops with eating establishments, it was still clear that food was the key item bought. Indeed, 68 per cent of respondents had bought food from, for example, delicatessens, butchers and other shops that often sold local produce. Although 51 per cent of respondents had visited craft/art shops, only 16 per cent noted that they had bought something. Other popular purchases were clothes (28 per cent) and books ( 21 per cent). Overall there was a tendency towards convenience products ( 75 per cent) compared to comparison (59 per cent). With the comparison products noted tending to be small.

The activities listed in Table 3 were largely undertaken in the top four towns presented within Table 1, with Corbridge perhaps exceeding 
expectations and perhaps Morpeth underperforming. Indeed, steeped in history, Corbridge is seen locally to have been very successfully developing a niche in quality boutiques shops, food shops, coffee shops and restaurants, where a number of 19th century decorated shop fronts still survive. Whereas Morpeth is still important in terms of linkages with its rural hinterland, the size of Corbridge (population approximately 3,000 ) and its location in close proximity to the larger town of Hexham suggested it needed to find another identity and it would appear to have been successful in achieving this. The situation in Morpeth is discussed in detail below.

The methods used by respondents to find out about towns to visit and activities available varied, but the key methods were friends and family (41 per cent), the internet (35 per cent), library/tourist information/tourist leaflets ( 21 per cent) and the local newspaper ( 21 per cent). Interestingly, the comparatively cheap method of promotion through the internet was very popular, putting pressure on country towns to have a quality and up-to-date website.

\section{CASE STUDY: FINDING A FUTURE FOR MORPETH}

The results have demonstrated how Morpeth is one of the top three typical market towns in the northeast and in the top three most visited. Indeed, it has one of the four main tourist information centres in the county of Northumberland. Towns such as Corbridge, however, seem to be performing better, engaging urban residents in visiting their shops, for example. Both towns are located in close proximity to the North Tyne conurbation and other nearby towns; however, Morpeth differs to Corbridge in terms of its size $(13,500$ compared to 3,000$)$ and the extent to which it acts as a rural service centre. Indeed, a survey of 415 Morpeth visitors undertaken in the summer of 2005 suggested those living in Morpeth and nearby villages to provide the bulk of the trade for its centre (50 per cent from the town itself, 30 per cent from nearby villages and 16 per cent from nearby towns) with only 5 per cent of visitors coming from large urban areas. As such, any initiatives to try and encourage urban visitors within Morpeth should also consider how consistent these changes are with the desires of the 'core' visitors.

At the time of the survey, the convenience and comparison retail trade for shops in Morpeth town centre was in decline and the situation would appear to be much worse than national trends. Based on a survey of retailers, the results showed financial and professional services and retail services (eg hairdressing, beauty salons and photo services) performance to be ok/good and there to be optimism. In contrast to other comparison retail, charity shops also appeared to be performing well. Generally, the trading conditions were poor. Although, it is not clear from these statistics how close the businesses were to closing, if these trends were to continue, Morpeth town centre is likely to see a shift towards financial and professional services, service retail and charity shops. The availability of convenience and comparison retail is likely to decline and the attraction of the town to the leisure shopper to diminish. 
Table 4: What residents like about shopping in Morpeth

\begin{tabular}{ll}
\hline Topic & $\begin{array}{l}\text { Those } \\
\text { responding (\%) }\end{array}$ \\
\hline Close/convenient/handy & 36 \\
Specialist/independent shops & 22 \\
Choice/variety & 17 \\
Friendly (shops and people) & 16 \\
Nice/pleasant & 14 \\
Compact/small town & 9 \\
Good shops & 9 \\
Market town & 4 \\
Atmosphere & 3 \\
Sample (those responding) & 184 \\
\hline
\end{tabular}

A survey of residents within Morpeth and the nearby village of Pegswood (325 questionnaires completed at a response rate of 50 per cent) asked similar open-ended questions to those within the urban resident survey. Table 4 shows the responses to a question asking what residents like about shopping in Morpeth. With the background of a sizeable leakage out of the town in terms of trade, ${ }^{26}$ there would appear to be two types of respondents: those hoping to do their main comparisonshopping in Morpeth or at least increase their use of the town; and those looking for something different from the city. Clearly, there are some overlaps between these groups; however, they beg the question as to what extent the town's identity is generated from it being a rural service centre or a leisure shopping location. For those wishing to continue doing their main comparison-shopping in Newcastle, they probably see Morpeth in terms of a place for the occasional leisure shopping experience, where they do something different from the norm. For those hoping to do more shopping in Morpeth they may be encouraged by its natural advantages in terms of its location (close/convenient/handy, 36 per cent), but also the friendly nature of the town (shops and people) (16 per cent) and its compact/small size ( 9 per cent). For such respondents, there is a desire for greater choice and variety within the shops ( 22 per cent) and calls for high street chain stores. In the case of the occasional leisure shopper, it is the specialist/independent shops (22 per cent) that are appealing and, indeed, their tastes are unlikely to be much different to those living in Newcastle. This dichotomy was also observed when respondents were asked what could be improved to encourage them to shop more in the town. Table 5 suggests that the desire for more clothes shops, high street/chain stores/multiples and bigger and better supermarkets was stronger than the need for more independent shops. As such, these are the needs of the 'core' shoppers. Leisure shoppers remain a minority but important group and any changes to appease the 'core' shoppers should not detract from the overall appeal of the town providing a shopping experience that is different from the city.

Table 5 also demonstrates a need as part of this strategy to enhance the convenience of visiting the town through measures to reduce parking charges. Whereas urban residents are also concerned with parking charges, as the charges tend to be cheaper than in city centres, the results 
Table 5: How to encourage customers to visit Morpeth more for shopping

\begin{tabular}{lc}
\hline Topic & Those responding (\%) \\
\hline Better shops/wider variety of shops & 55 \\
Less charity shops & 15 \\
Need more clothes shops & 13 \\
High street/chain stores/multiples & 6 \\
More independent shops & 4 \\
Better supermarkets & 6 \\
Parking & 45 \\
Parking charges & 37 \\
More parking spaces & 7 \\
Sample (those responding) & 269 \\
\hline
\end{tabular}

suggest urban residents are more concerned with convenience in terms of finding spaces in which to park and proximity of the town centre from the car park.

In response to current difficulties in the town, major redevelopment work of the central marketplace occurred in 2003. The central marketplace is soon to be used again as a location for an improved market. This should be an important attraction for leisure shoppers and, more generally, enhance the identity and 'traditional' appeal of the town. The disruption, however, caused by this development has affected trade and the more functional shopper using their rural service centre. More recent efforts have focused on the 'core' business, with a parking scheme being introduced that provides free parking for residents of the Borough Council at non-peak times. Further major developments are currently at the consultation stage that would provide mixed retail accommodation, extra high street multiple retailers and extra car parking spaces. In order to maintain the interest of the leisure shopper, it will be important that the traditional feel of the town is not lost and the independent/specialist shops remain. It will be interesting to follow how the balancing of the leisure shopper with desires of the more functional shopper visiting their rural service centre is achieved in the future.

\section{CONCLUSION}

This paper has explored urban attitudes towards country towns and considered their potential as visitor attractions, both in terms of how to attract urban residents but also achieving this in a manor that is consistent with the needs of rural residents.

The term 'market town' was found to carry colloquial meaning and of relevance to the marketing of country towns. The term implies many things with a key aspect being 'different from the city'. Market towns are seen to be small, rural and steeped in history and tradition, with rural hinterland linkages seen to be particularly important. The shopping experience in country towns is a key difference from large urban areas, where shops were thought to have more character, individuality, be more local and specialist in nature. These aspects attract urban visitors and need to be encouraged and enhanced to increase visitor numbers. Market 
towns, however, were seen to be only a sub-group of towns, where others are defined in terms of their location to the coast, proximity to large urban areas and other functional roles beyond rural service centre. As such care is needed when using the term within marketing.

It was interesting to note that the most typical market towns also have the highest visitor rates from urban residents. The most common activities of urban visitors were to purchase snacks/refreshments/meals and visit gardens or historic buildings. Also common was shopping in craft/art shops and specialist food shops. A sizeable minority of respondents had also previously visited regular and farmers markets in the towns. A large proportion of respondents saw visiting country towns as the main purpose of their day out and, as such, the towns need to have sufficient activities for visitors to stay for the whole day. With regard to those respondents who just visit towns as part of their day out in the countryside, proximity to other visitor attractions near to the town (seaside, national parks, etc.) was found to be important. Generally, in terms of publicity a good up-todate internet site was found to be very important.

For historic towns whose 'core' trade has been significantly lost to other larger towns and urban areas, the results provide hope that they can refocus themselves as leisure shopping locations. For others, town and hinterland residents provide the most important trade and, although custom from urban residents is important, it is crucial that any initiatives to encourage urban residents do not adversely affect their rural service centre role. The case of Morpeth has illustrated the challenges of meeting the needs of both residents and urban visitors. If towns are made more attractive, convenient to access, and their character as 'market towns' is enhanced, this may help to encourage residents and visitors to use the town. Indeed, a number of residents may visit the town for the occasional leisure shopping experience. The presence of multiple retailers may discourage urban visitors, for whom the 'difference from the city' is crucial. Balancing the needs of the leisure shopper with the desires of the more functional shopper visiting their rural service centre will remain a challenge for the future.

\section{References and Notes}

1. Powe, N.A. \& Shaw, T. (2003). Market town centres: exploring the service role through visitor surveys. Planning Practice and Research 18(1), 37-50.

2. Powe, N.A. \& Shaw, T. (2004). Exploring the current and future role of market towns in servicing their hinterlands: a case study of Alnwick in the North East of England. Journal of Rural Studies 20(4), 405-418.

3. Shorten, J. (2004). New light on country life. Town and Country Planning 73(6), 186-191.

4. Pinkerton, J., Hassinger, E. \& O'Brian, D. (1995). Inshopping by residents of small communities. Rural Sociology 60, 467-480.

5. Robertson, K.A. (1997). Downtown retail revitalization: a review of American development strategies. Planning Perspectives 12, 383-401.

6. Collis, C., Berkeley, N. \& Fletcher, D.R. (2000). Retail decline and policy responses in district shopping centers. Town Planning Review 71(2), 149-168.

7. Thomas, C.J. \& Bromley, R.D.F. (2002). The changing competitive relationship between small town centres and out-of-town retailing: town revival in South Wales. Urban Studies 39(4), 791-817.

8. Considering the period since 1980, it has been estimated that there has been little change in the real cost of motoring, however, disposable income has increased by over $90 \%$. As such the real cost of motoring has fallen considerably as a proportion of disposable income. 
9. Department for Transport (2005). Transport trends. Department for Transport, http://www.dft. gov.uk/stellent/groups/dft_transstats/documents/downloadable/dft_transstats_035650.pdf, Accessed 8th May 2006.

10. Market towns are generally defined in England to have a population somewhere between 2,000 and 30,000 .

11. Ministry of Agriculture, Fisheries and Food and Department of Environment, Transport and the Regions (2000). Our Countryside: the Future. A Fair Deal for Rural England, Cm 49409, The Stationery Office, London.

12. Thompson, D. (1995). The Concise Oxford Dictionary, 9th edn, Clarendon Press, Oxford.

13. Foot and mouth is a non-fatal disease which affects cloven-hoofed animals. With the outbreak of the disease, the UK government restricted access to some areas of the countryside as a measure to prevent further spread of the disease. Access to country towns was not restricted.

14. Williams, C. \& Ferguson, M. (2005). Recovering from crisis: strategic alternatives for leisure and tourism providers based within a rural economy. International Journal of Public Sector Management 18(4), 350-366.

15. Powe, N.A., Hart, T. \& Shaw, T. (Forthcoming) Finding a Sustainable Future for Market Towns: Principles and Practice, Routledge, London.

16. Simms, A., Kjell, P. \& Potts, R. (2005). Clone town Britain survey: the survey results on the bland state of the nation'. New Economics Foundation. http://www.neweconomics.org/gen/ uploads/t3zly355dpog3w55ctaiuu4506062005082504.pdf, Accessed 8th May 2006.

17. Countryside Agency (2004). The State of the Countryside 2004, Countryside Agency Publications, Wetherby, available from http://www.countryside.gov.uk/Publications/articles/ Publication_tcm2 19379.asp, Accessed 8th May 2006.

18. Richardson, R. \& Powe, N.A. (2004). Service implications of population growth in market towns. Planning Practice and Research 19(4), 363-373.

19. Cheshire, P.C. \& 'Stabler', M.J. (1976). Joint consumption benefits in recreational site surplus; an empirical estimate. Regional Studies, 10 May, 346-351.

20. Cooper, C., Fletcher, J., Gilbert, D., Shepard, R. \& Wanhill, S. (1998). Tourism: Prinipcles and Practice, 2nd edn, Longman, Harlow.

21. Faulkner, B., Moscardo, G. \& Laws, E. (2001). Tourism in the 21st Century: Lessons From Experience, Continuum, London.

22. Morgan, D.L. (1997). Focus Groups as Qualitative Research, Qualitative Research Methods Series, Vol 16, 2nd edn, Sage Publications Ltd, London.

23. Powe, N.A. (2005). Evaluation of Trading Conditions in Morpeth, Morpeth for Castle Morpeth Borough Council and Morpeth \& District Chamber of Trade, unpublished document.

24. These details are available from the author.

25. Wikipedia (2006). National Trust for Places of Historic Interest or Natural Beauty, http://en. wikipedia.org/wiki/National_Trust_for_Places_of_Historic_Interest_or_Natural_Beauty, Accessed 31st March 2006.

26. Although most people living in and around the town still shop regularly for food, they are more likely to shop elsewhere for comparison goods. 